University of Nebraska - Lincoln

DigitalCommons@University of Nebraska - Lincoln

Faculty Publications from the Harold W. Manter Laboratory of Parasitology

Parasitology, Harold W. Manter Laboratory of

2005

\title{
Trichinella pseudospiralis from a Wild Pig in Texas
}

H. Ray Gamble

Animal Parasitic Diseases Laboratory, Agricultural Research Seervice, United States Department of Agriculture, rgamble@nas.edu

E. Pozio

Istituto Superiore di Sanita

J. Ralph Lichtenfels

Animal Parasitic Disease Lab, Agricultural Research Service, United States Department of Agriculture, 2jrcgl@gmail.com

D. S. Zarlenga

Animal Parasitic Diseases Laboratory, Agricultural Research Seervice, United States Department of Agriculture

D. E. Hill

Animal Parasitic Diseases Laboratory, Agricultural Research Seervice, United States Department of Agriculture

Follow this and additional works at: https://digitalcommons.unl.edu/parasitologyfacpubs

Part of the Parasitology Commons

Gamble, H. Ray; Pozio, E.; Lichtenfels, J. Ralph; Zarlenga, D. S.; and Hill, D. E., "Trichinella pseudospiralis from a Wild Pig in Texas" (2005). Faculty Publications from the Harold W. Manter Laboratory of Parasitology. 628.

https://digitalcommons.unl.edu/parasitologyfacpubs/628

This Article is brought to you for free and open access by the Parasitology, Harold W. Manter Laboratory of at DigitalCommons@University of Nebraska - Lincoln. It has been accepted for inclusion in Faculty Publications from the Harold W. Manter Laboratory of Parasitology by an authorized administrator of DigitalCommons@University of Nebraska - Lincoln. 


\title{
Trichinella pseudospiralis from a wild pig in Texas
}

\author{
H.R. Gamble ${ }^{\mathrm{a}, *}$, E. Pozio ${ }^{\mathrm{b}}$, J.R. Lichtenfels ${ }^{\mathrm{a}}$, D.S. Zarlenga ${ }^{\text {a }}$, D.E. Hill ${ }^{\text {a }}$ \\ ${ }^{a}$ U.S. Department of Agriculture, Agricultural Research Service, Animal Parasitic Diseases Laboratory, \\ Building 1040, BARC-East, Beltsville, MD 20705, USA \\ ${ }^{\mathrm{b}}$ Department of Infectious Parasitic and Immunomediated Diseases, Istituto Superiore di Sanita, \\ Viale Regina Elena, 29900161 Rome, Italy
}

\begin{abstract}
In December 2001, the routine inspection of a wild boar intended for human consumption revealed the presence of Trichinella ssp. larvae. Biological, morphological and genetic analyses demonstrated the parasite to be Trichinella pseudospiralis. This is the second report of T. pseudospiralis in the United States and the first report of the parasite in a food animal species in the U.S.

(C) 2005 Elsevier B.V. All rights reserved.

Keywords: Trichinella pseudospiralis; Wild boar; Meat inspection

\section{Introduction}

Trichinella pseudospiralis is one of two species of the genus Trichinella that do not form a capsule in the host. First reported from Russia (Garkavi, 1972), this species has been found to occur in a wide range of hosts including wild carnivores, carnivorous birds, marsupials, rodents and pigs in Asia, Europe,

inspection program for Trichinella in pork, horsemeat and game meats. Inspectors in this program test tissues from meat intended for export using the pooled sample digestion method. In December 2001, a positive test result was recorded for tissue from a wild boar harvested in the state of Texas. We report here on the identification of this isolate of Trichinella as $T$. pseudospiralis.
\end{abstract} Australia and North America (Kapel, 2000). Its role in human disease has been reported in New Zealand, Thailand and France (Jongwutiwes et al., 1998; Dupouy-Camet, 2000; Ranque et al., 2000).

The U.S. Department of Agriculture (USDA), Agricultural Marketing Service, administers an

\footnotetext{
* Corresponding author at: National Research Council, 500 Fifth Street NW, GR300K, Washington, DC 20001, USA.

Tel.: +1 202334 2787; fax: +1 2023342759 .

E-mail address: rgamble@nas.edu (H.R. Gamble).
}

\section{Materials and methods}

Diaphragm tissue samples from a wild pure Russian boar (Sus scrofa) that had tested positive for Trichinella sp. at slaughter were shipped to the USDAs Animal Parasitic Diseases Laboratory in Beltsville, Maryland, USA. The worm burden of infected boar tissue was determined by artificial 
digestion as previously described (Gamble et al., 1999). Recovered larvae were counted and passed into female Swiss Webster mice (100-500 larvae/mouse). Mice were killed at 6 and 26 weeks after inoculation and tissues were examined microscopically by compression of small pieces of diaphragm. Additional tissues were subjected to artificial digestion and recovered larvae were used for morphological and genetic analyses.

Individual male and female muscle larvae, recovered from Swiss Webster mice, were measured as previously described (Gamble et al., 1989). For genetic typing, larvae were tested by a multiplex polymerase chain reaction (PCR) for single larvae, as described by Pozio and La Rosa (2003), using ExTaq DNA polymerase from Takara in $50 \mathrm{ml}$ containing $1.5 \mathrm{mM} \mathrm{MgCl} 2,200 \mathrm{mM}$ dNTPs, 50 pmol of each primer and 0.5 unit of ExTaq DNA polymerase.

For further characterization, two mitochondrial genes [cytochrome oxidase subunit I (CO I) and the large subunit ribosomal-DNA (mt-lsrDNA)] and the expansion segment V (ESV) were studied. Since multiple bands have been observed in some ESV amplification products, individual bands were cloned prior to sequencing. The primer set oTsr1 $\left(5^{\prime}\right.$-CGA AAA CAT ACG ACA ACT GC) and oTsr4 (5'-GTT CCA TGT GAA CAG CAG T) was used to enzymatically amplify the ESV (Zarlenga and Dame, 1992; Zarlenga et al., 1996). Amplifications consisted of 35 cycles, as follows: denaturation at $94{ }^{\circ} \mathrm{C}$ for $30 \mathrm{~s}$, annealing at $58{ }^{\circ} \mathrm{C}$ for $30 \mathrm{~s}$, and elongation at $72{ }^{\circ} \mathrm{C}$ for $60 \mathrm{~s}$. The PCR amplified fragments from purified DNA were visualized by low resolution agarose gel electrophoresis (1.5\% standard agarose) (IBI). Finer resolution of the polymorphism among non-encapsulated isolates required higher resolution agarose gels (3.0\% metaphor agarose) (FMC). The primer set SB5 (forward 5'-GGTATAAGGGAAAGCCGGAA and reverse 5'-CACTCACATTGTAT GCCAAG) was used to amplify a $680 \mathrm{bp}$ repetitive DNA fragment specific for $T$. pseudospiralis according to the published protocol (Wu et al., 1999). A 419 bp region of the CO I gene was amplified by PCR with the primer set L6625 (5'-TTYTGRTTYTTYGGNCAYCC) and H7005 (5' ACNACRTARTANGTRTCRTG) (Nagano et al., 1999). A portion (445 bp) of the mt-lsrRNA gene was amplified by PCR using the primer set P753 (5'WACAATGGTCCTTTCG TACT) and P754 (5'-
TGAGGACATTAAGGTAGC). For the amplification of CO I and mt-lsrRNA genes, PCR was carried out for 35 cycles, each consisting of $30 \mathrm{~s}$ at $94{ }^{\circ} \mathrm{C}, 60 \mathrm{~s}$ at $50{ }^{\circ} \mathrm{C}$, and $60 \mathrm{~s}$ at $72{ }^{\circ} \mathrm{C}$. Nine Trichinella reference strains were used for the comparison: $T$. spiralis (code ISS3), T. nativa (code ISS10), T. britovi (code ISS2), $T$. murrelli (code ISS35), T. nelsoni (code ISS37), T. papuae (code ISS572), and, because of the genetic variability of $T$. pseudospiralis, three strains of this species from different zoogeographical regions [one each from the Nearctic region (code ISS470), the Palearctic region (code ISS13) and the Australian region (ISS141)] (Pozio et al., 2001).

\section{Results}

The infected boar in this study was harvested near Newcastle, Texas (Longitude $98^{\circ} 44^{\prime} \mathrm{W}$, Latitude $33^{\circ} 12^{\prime} \mathrm{N}$ ) and was identified as Trichinella positive during routine testing using a $1 \mathrm{~g}$ sample. Digestion of $23 \mathrm{~g}$ of diaphragm tissue from this boar yielded 3300 larvae for a worm burden of 143.5 larvae per gram (LPG) of tissue.

Tissues of infected mice examined 6 and 26 weeks after inoculation showed larvae that were not encapsulated (Fig. 1), indicating they were one of two Trichinella species that do not form a capsule in host musculature. Larvae recovered from mice measured $684 \pm 29 \mu \mathrm{m}$ for female worms and $672 \pm 29 \mu \mathrm{m}$ for male worms.

Initial genetic analysis by multiplex PCR analysis indicated the species to be $T$. pseudospiralis. Subsequent analysis of cytochrome oxidase subunit I, the large subunit ribosomal DNA, and expansion segment $\mathrm{V}$ genes placed this isolate in the Nearctic population.

The isolate of T. pseudospiralis was contributed to the International Trichinella Reference Centre as Isolate Code (ISS) 1132.

\section{Discussion}

In a previous study, we reported T. pseudospiralis from a carnivorous bird in Alabama, USA (Lindsay et al., 1995); however, this species has not previously been reported in a food animal species in the United 


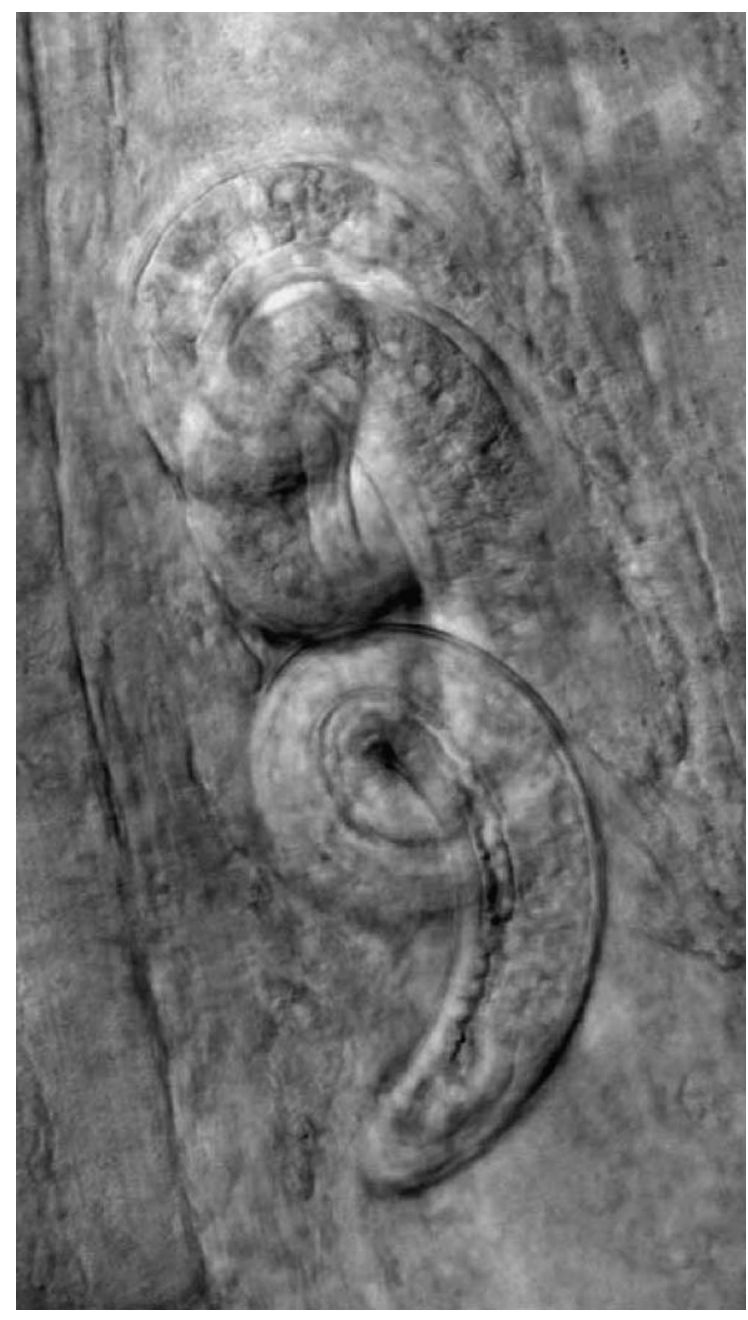

Fig. 1. Trichinella pseudospiralis larvae recovered from a wild boar in Texas, USA. Larvae were passed once in Swiss Webster mice. Tissue is from a mouse diaphragm recovered 26 weeks after inoculation of 100 larvae.

States. This report extends the range of T. pseudospiralis in the U.S. and adds to the list of reported host species.

This was the first report of Trichinella in wild boar inspected for slaughter since the inception of the testing program in 1996. Other studies conducted in our laboratory have tested additional samples of wild boar from Texas, with negative results for Trichinella infection. From July 1997 through June 1998, 226 samples were collected from wild boar harvested by the Texas Department of Parks and Wildlife. Animals were harvested by trapping, ground shooting or aerial shooting. Testing was performed by digestion of 10 $100 \mathrm{~g}$ of diaphragm tissue (207 animals) and/or ELISA (187 animals). All results were negative. Animals tested in that study came from Cottle, Dickens, Foard, King, and Motley counties in North central Texas. The positive animal in this study came from Young county, which is very close to the other counties surveyed. The combination of these data suggests that the overall prevalence of Trichinella is quite low in wild boar in this region. In contrast, prevalence rates of $2-15 \%$ have been reported in feral pigs in New England states (Worley et al., 1994; Gamble, unpublished).

Pigs, horses and feral swine slaughtered for export are tested for Trichinella infection by the pooled sample digestion method. This program is administered by the USDAs Agricultural Marketing Service. Currently, five pork facilities, three horse facilities, and one wild game facility are enrolled in the program. Since inception of the program, no positive horses have been identified and there has only been one report of a positive pig, with only 1 larva recovered. This is the first finding of Trichinella in feral pigs since the USDA testing program has begun. Further, it is the first report of T. pseudospiralis in a food animal species in the U.S. Because $T$. pseudospiralis is a human pathogen (Ranque et al., 2000), care should be taken in inspecting feral pigs and other game meats for this parasite; testing should be performed by artificial digestion and not by compression or trichinoscopy methods which will not detect T. pseudospiralis.

\section{References}

Dupouy-Camet, J., 2000. Trichinellosis: a worldwide zoonosis. Vet. Parasitol. 93, 183-190.

Gamble, H.R., Brady, R.C., Bulaga, L.L., Berthoud, C.L., Smith, W.G., Detweiler, L.A., Miller, L.E., Lautner, E.A., 1999. Prevalence and risk factors for trichinellosis in domestic pigs in the northeastern United States. Vet. Parasitol. 82, 59-69.

Gamble, H.R., Lichtenfels, J.R., Purcell, J.P., 1989. Light and scanning electron microscopy of the ecdysis of Haemonchus contortus infective larvae. J. Parasitol. 75, 303-307.

Garkavi, B.L., 1972. The species of Trichinella isolated from wild carnivores. Veterinariia 10, 90-91.

Jongwutiwes, S., Chantachum, N., Kraivichian, P., Siriyasatien, P., Putaporntip, C., Tamburrini, A., La Rosa, G., Sreesunpasirikul, C., Yingyourd, P., Pozio, E., 1998. First outbreak of human 
trichinellosis caused by Trichinella pseudospiralis. Clin. Inf. Dis. 26, 111-115

Kapel, C.M.O., 2000. Host diversity and biological characteristics of Trichinella genotypes and their effects on transmission. Vet. Parasitol. 93, 263-278.

Lindsay, D.S., Zarlenga, D.S., Gamble, H.R., Al-Yaman, F., Smith, P.C., Blagburn, B.L., 1995. Isolation and characterization of Trichinella pseudospiralis Garkavia, 1972 from a black vulture (Coragyps atratus) from Alabama. J. Parasitol. 81, 920-923.

Nagano, I., Wu, Z., Matsuo, A., Pozio, E., Takahashi, Y., 1999. Identification of Trichinella genotypes by polymerase chain reaction-restriction fragment length polymorphism of mitochondrial cytochrome c oxidase subunit I gene. Int. J. Parasitol. 29, 1113-1120.

Pozio, E., La Rosa, G., D’Ancona, F., Amati, M., Mancini Barbieri, F., De Giacomo, M., 2001. Twelve years of activity of the international Trichinella reference centre. Parasite 8, S44-S46.

Pozio, E., La Rosa, G., 2003. PCR-derived methods for the identification of Trichinella parasites from animal and human samples. Meth. Mol. Biol. 216, 299-309.
Ranque, S., Faugere, B., Pozio, E., La Rosa, G., Tamburrini, A., Pellissier, J.-F., Brouqui, P., 2000. Trichinella pseudospiralis outbreak in France. Emer. Inf. Dis. 6, 543-547.

Worley, D.E., Seesee, F.M., Zarlenga, D.S., Murrell, K.D., 1994. Attempts to eradicate trichinellosis from a wild boar population in a private game park (USA). In: Campbell, W.C., Pozio, E., Bruschi, F. (Eds.), Trichinellosis. Istituto Superiore di Sanita Press, Rome, pp. 611-616.

Wu, Z., Nagano, I., Pozio, E., Takahashi, Y., 1999. Polymerase chain reaction-restriction fragment length polymorphism (PCRRFLP) for the identification of Trichinella. Parasitology 118, 211-218.

Zarlenga, D.S., Aschenbrenner, R.A., Lichtenfels, J.R., 1996. Variations in microsatellite sequences provide evidence for population differences and multiple ribosomal gene repeats within Trichinella pseudospiralis. J. Parasitol. 82, 534-538.

Zarlenga, D.S., Dame, J.B., 1992. The identification and characterization of a break within the large subunit ribosomal RNA of Trichinella spiralis: comparison of gap sequences within the genus. Mol. Biochem. Parasitol. 51, 281-289. 